\title{
Front Matter: Volume 9976
}

, "Front Matter: Volume 9976," Proc. SPIE 9976, Imaging Spectrometry XXI, 997601 (7 November 2016); doi: 10.1117/12.2260592

SPIE Event: SPIE Optical Engineering + Applications, 2016, San Diego, California, SPIE. United States 


\section{PROCEEDINGS OF SPIE}

\section{Imaging Spectrometry XXI}

John F. Silny

Emmett J. Ientilucci

Editors

29-30 August 2016

San Diego, California, United States

Sponsored and Published by

SPIE 
The papers in this volume were part of the technical conference cited on the cover and title page. Papers were selected and subject to review by the editors and conference program committee. Some conference presentations may not be available for publication. Additional papers and presentation recordings may be available online in the SPIE Digital Library at SPIEDigitallibrary.org.

The papers reflect the work and thoughts of the authors and are published herein as submitted. The publisher is not responsible for the validity of the information or for any outcomes resulting from reliance thereon.

Please use the following format to cite material from these proceedings:

Author(s), "Title of Paper," in Imaging Spectrometry XXI, edited by John F. Silny, Emmett J. lentilucci, Proceedings of SPIE Vol. 9976 (SPIE, Bellingham, WA, 2016) Six-Digit Article CID Number.

ISSN: 0277-786X

ISSN: 1996-756X (electronic)

ISBN: 9781510603431

ISBN: 9781510603448 (electronic)

Published by

SPIE

P.O. Box 10, Bellingham, Washington 98227-0010 USA

Telephone +1 3606763290 (Pacific Time) · Fax +1 3606471445

SPIE.org

Copyright (C) 2016, Society of Photo-Optical Instrumentation Engineers.

Copying of material in this book for internal or personal use, or for the internal or personal use of specific clients, beyond the fair use provisions granted by the U.S. Copyright Law is authorized by SPIE subject to payment of copying fees. The Transactional Reporting Service base fee for this volume is $\$ 18.00$ per article (or portion thereof), which should be paid directly to the Copyright Clearance Center (CCC), 222 Rosewood Drive, Danvers, MA 01923. Payment may also be made electronically through CCC Online at copyright.com. Other copying for republication, resale, advertising or promotion, or any form of systematic or multiple reproduction of any material in this book is prohibited except with permission in writing from the publisher. The CCC fee code is 0277-786X/16/\$18.00.

Printed in the United States of America.

Publication of record for individual papers is online in the SPIE Digital Library.

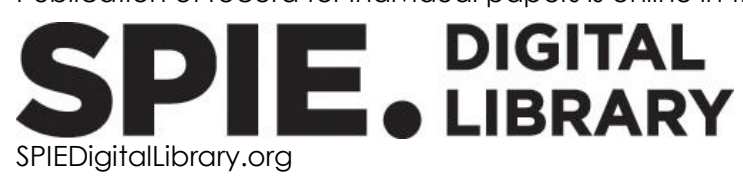

Paper Numbering: Proceedings of SPIE follow an e-First publication model, with papers published first online and then in print. Papers are published as they are submitted and meet publication criteria. A unique citation identifier (CID) number is assigned to each article at the time of the first publication. Utilization of CIDs allows articles to be fully citable as soon as they are published online, and connects the same identifier to all online, print, and electronic versions of the publication. SPIE uses a six-digit CID article numbering system in which:

- The first four digits correspond to the SPIE volume number.

- The last two digits indicate publication order within the volume using a Base 36 numbering

system employing both numerals and letters. These two-number sets start with 00, 01, 02, 03, 04, $05,06,07,08,09,0 A, 0 B \ldots 0 Z$, followed by 10-1Z, 20-2Z, etc.

The CID Number appears on each page of the manuscript. The complete citation is used on the first page, and an abbreviated version on subsequent pages. 


\title{
Contents
}

\author{
$\checkmark \quad$ Authors \\ vii Conference Committee \\ ix Introduction
}

\section{SESSION 1 SPECTROMETER DESIGN AND PERFORMANCE}

997604 Mako airborne thermal infrared imaging spectrometer: performance update [9976-3]

997605 Compact Wide swath Imaging Spectrometer (CWIS): alignment and laboratory calibration [9976-4]

997606 Littrow spectrographs for moderate resolution infrared applications [9976-5]

997607 Data processing for a multi-slit LWIR HSI spectrometer [9976-6]

\section{SESSION 2 SPECTROMETER DESIGN AND MODELING}

997609 Capturing complete spatial context in satellite observations of greenhouse gases [9976-9]

9976 OA Resolution modeling of dispersive imaging spectrometers [9976-10]

SESSION 3 RADIATIVE TRANSFER, BIOLOGY, AND APPLICATIONS

9976 OB Principle component analysis and linear discriminant analysis of multi-spectral autofluorescence imaging data for differentiating basal cell carcinoma and healthy skin [9976-11]

9976 0C Raman hyperspectral imaging of iron transport across membranes in cells [9976-12]

9976 OE In-scene LWIR downwelling radiance estimation [9976-14]

9976 OF HT-FRTC: a fast radiative transfer code using kernel regression [9976-15]

\section{SESSION 4 DETECTION AND DATA CHARACTERIZATION}

9976 OG Clairvoyant fusion detection of ocean anomalies in WorldView-2 spectral imagery (Invited Paper) [9976-16]

$9976 \mathrm{OH}$ Statistical modeling of natural backgrounds in hyperspectral LWIR data [9976-17] 
9976 OI New SHARE 2010 HSI-LiDAR dataset: re-calibration, detection assessment and delivery [9976-18]

9976 OJ Mitigating noise in global manifold coordinates for hyperspectral image classification [9976-19]

\section{SESSION 5 CLASSIFICATION AND UNMIXING}

9976 OK Identifying vehicles with VNIR-SWIR hyperspectral imagery: sources of distinguishability and confusion [9976-20]

$99760 \mathrm{M}$ Abundance estimation of solid and liquid mixtures in hyperspectral imagery with albedobased and kernel-based methods [9976-22]

\section{SESSION $6 \quad$ REMOTE SENSING SATELLITES AND PROCESSING}

997600 Spectral reflectance inversion with high accuracy on green target [9976-24]

9976 OP Detection limit of fishing boats by the Day Night Band (DNB) on VIIRS [9976-25]

$99760 Q \quad$ Object-based illumination normalization for multi-temporal satellite images in urban area [9976-26]

\section{SESSION 7 DATA PROCESSING}

9976 OS A comprehensive analysis on relevance of four hyperspectral data exploitation methods: LS, OSP, MTMF and MF-FAM [9976-28]

9976 OT Remote sensing image segmentation using local sparse structure constrained latent low rank representation [9976-29]

9976 OV Spectrum recovery method based on sparse representation for segmented multi-Gaussian model [9976-31]

\section{POSTER SESSION}

9976 OX Towards low cost photoacoustic Microscopy system for evaluation of skin health [9976-33]

9976 OY Research of building information extraction and evaluation based on high-resolution remote-sensing imagery [9976-34]

$9976 \mathrm{OZ}$ Remote sensing of the atmosphere using three-directional scanning-Lidar technique [9976-35] 


\section{Authors}

Numbers in the index correspond to the last two digits of the six-digit citation identifier (CID) article numbering system used in Proceedings of SPIE. The first four digits reflect the volume number. Base 36 numbering is employed for the last two digits and indicates the order of articles within the volume. Numbers start with 00, 01, 02, 03, 04, 05, 06, 07, 08, 09, 0A, 0B...0Z, followed by 10-1Z, 20-2Z, etc.

Adler-Golden, Steven, OK Allen, David W., OM Allman, Eric, OG Asanuma, Ichio, OP Bachmann, Charles M., OJ Bai, Tingzhu, 00 Barroso, Margarida, OC Bely, Nicholas, OX Boucher, Richard H., 04 Brooks, Cynthia, 09 Brueggeman, M., OE Buckland, Kerry N., 04 Cao, Qiong, OY Cherkasova, Olga P., OB Chernomyrdin, Nikita $\vee$., $O B$ Cooley, Thomas, $\mathrm{OE}, \mathrm{OH}$ Costa, Xavier Felipe, OC Das, Anupam, OC Eldering, Annmarie, 09 Fatima, Afreen, OX Frankenberg, Christian, 09 Green, R. O., 05

Gu, Lingjia, OY

Gutierrez, David J., 04

Hall, Jeffrey L., 04

Hao, Wei Min, OZ

Hariri, Ali, OX

Havemann, Stephan, OF

Huang, Weiting, OS

Ientilucci, Emmett J., Ol

Jacobson, J., OE

Jaffe, Daniel T., 09

Jiang, Le, 00

Jin, Can, OJ

Jin, Jianzhou, 00

Keim, Eric R., 04

Khmaladze, Alexander, OC

Kovalev, V., 0 Z

Kudrin, Konstantin G., OB

Kuhnert, Andreas C., 09

Kurlov, Vladimir N., OB

Lampen, Sara, 06

Lesnichaya, Anastasiya D., OB

Lewis, Warren, OF

Li, Yong, 00

Liggett, E., 05

Liu, Shuogiong, 00

Mackin, Kenneth J., OP

Manolakis, Dimitris, $\mathrm{OE}, \mathrm{OH}$

Martin, Jacob A., 07

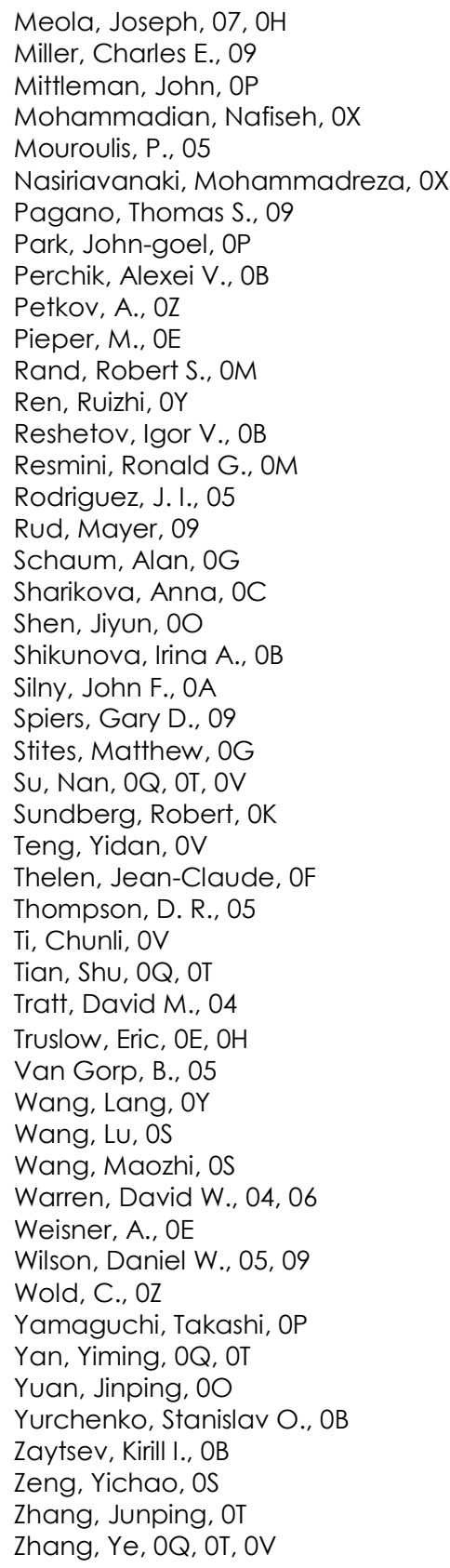


Proc. of SPIE Vol. $9976997601-6$

Downloaded From: https://www.spiedigitallibrary.org/conference-proceedings-of-spie on 25 Apr 2023 Terms of Use: https://www.spiedigitallibrary.org/terms-of-use 


\section{Conference Committee}

Program Track Chair

Allen H.-L. Huang, University of Wisconsin-Madison (United States)

Conference Chairs

John F. Silny, Raytheon Space \& Airborne Systems (United States)

Emmett J. lentilucci, Rochester Institute of Technology (United States)

Conference Program Committee

Christoph C. Borel, Air Force Institute of Technology (United States)

Thomas G. Chrien, Aerospace Corporation (United States)

Thomas Cooley, Air Force Research Laboratory (United States)

Eustace L. Dereniak, College of Optical Sciences, The University of Arizona (United States)

Robert O. Green, Jet Propulsion Laboratory (United States)

Steven A. Macenka, Jet Propulsion Laboratory (United States)

Mehrube Mehrubeoglu, Texas A\&M University Corpus Christi

(United States)

Joseph Meola, Air Force Research Laboratory (United States)

Pantazis Mouroulis, Jet Propulsion Laboratory (United States)

Thomas S. Pagano, Jet Propulsion Laboratory (United States)

Richard L. Wiggins, Corning Specialty Materials, Inc. (United States)

Session Chairs

1 Spectrometer Design and Performance

Pantazis Mouroulis, Jet Propulsion Laboratory (United States)

2 Spectrometer Design and Modeling

John F. Silny, Raytheon Space and Airborne Systems (United States)

3 Radiative Transfer, Biology, and Applications

Mehrube Mehrübeoglu, Texas A\&M University Corpus Christi

(United States)

4 Detection and Data Characterization

Emmett J. lentilucci, Rochester Institute of Technology (United States)

5 Classification and Unmixing

Emmett J. lentilucci, Rochester Institute of Technology (United States) 
6 Remote Sensing Satellites and Processing

Emmett J. Ientilucci, Rochester Institute of Technology (United States)

$7 \quad$ Data Processing

Emmett J. lentilucci, Rochester Institute of Technology (United States) 


\section{Introduction}

August 2016 marks SPIE's 21st Imaging Spectrometry conference. Over the years, the conference has accepted and published papers on a variety of spectroscopy topics, including: active and passive sensor designs, novel spectrometer designs and architectures, spectral modeling and measurements, atmospherics and radiative transfer, and spectral data algorithms and processing. Applications often touched upon the fields of Earth science, homeland security, and remote sensing.

The conference initially obtained enough submissions to accommodate a full day meeting. A few months before the conference, we absorbed approximately ten papers from another session that did not meet the minimum number of submissions to hold their own meeting. Thus, we added a second day. These additional papers addressed general remote sensing and data processing applications with less emphasis on spectroscopy. Nevertheless, we have decided to publish them in this proceedings volume.

We look forward to receiving submissions for the 22nd Imaging Spectrometry conference in 2017.

John F. Silny

Emmett J. lentilucci 
Proc. of SPIE Vol. 9976 997601-10

Downloaded From: https://www.spiedigitallibrary.org/conference-proceedings-of-spie on 25 Apr 2023 Terms of Use: https://www.spiedigitallibrary.org/terms-of-use 